\title{
ANALISIS PENGARUH LIKUIDITAS, PROFITABILITAS, LEVERAGE, OPERATING CAPACITY, DAN BIAYA AGENSI MANAJERIAL TERHADAP FINANCIAL DISTRESS
}

\author{
Arsinda Inggar Pawitri \\ Muniya Alteza \\ Universitas Negeri Yogyakarta \\ m_alteza@uny.ac.id
}

\begin{abstract}
The aim of this study was to determine the effect of liquidity, profitability, leverage, operating capacity, and managerial agency costs on financial distress in manufacturing companies listed on Indonesia Stock Exchange. The research period used was 2015-2017. The type of this research was associative causal with quantitative approach. The population of this study includes all manufacturing companies listed on Indonesia Stock Exchange. The sampling technique used was purposive sampling, and obtained as many as 84 companies, consists of 42 companies that experienced financial distress, and 42 companies that didn't experience financial distress as comparison company. Data analysis conducted through logistic regression. Based on this research, it was concluded that liquidity proxied by current ratio had no effect to financial distress. Profitability proxied by return on asset had no effect on financial distress. Leverage proxied by debt to asset ratio had a significant and possitive effect on financial distress. Operating capacity proxied with total asset turnover had no effect on financial distress. Managerial Agency costs had no effect on financial distress. The Nagelkerke $R$ Square's score in this study was 0.491 which means that the ability of liquidity, profitability, leverage, operating capacity, and managerial agency were able to explain the variable of financial distress condition by $49.1 \%$. The remaining of 50.9\% dependent variables were explained by other factors outside the model.
\end{abstract}

Keywords: Liquidity; Profitability; Leverage; Operating Capacity; Managerial Agency Costs; Financial Distress.

\section{PENDAHULUAN}

Dewasa ini perkembangan ekonomi dunia mengalami kemajuan yang sangat pesat. Bisnis yang kuat dan berpengalaman akan semakin mendapat keuntungan karena meluasnya pengaruh globalisasi. Akan tetapi di sisi lain, bisnis yang baru tumbuh ataupun bisnis yang masih berskala nasional akan sulit apabila ingin bersaing dengan perusahaan asing sehingga dampaknya adalah perusahaan tersebut akan mengalami financial distress (krisis keuangan) dalam perusahaan mereka.
Beberapa dampak buruk yang timbul akibat perkembangan globalisasi salah satunya adalah global financial crisis pada tahun 2008 yang berakibat pada melemahnya aktivitas bisnis secara umum. Sebagian besar negara di seluruh dunia mengalami kemunduran karena terjadinya krisis keuangan tersebut. Krisis keuangan telah menyebabkan kebangkrutan beberapa perusahaan publik di luar negeri. Di dalam negeri, terdapat beberapa dampak terjadinya krisis keuangan, salah satunya adalah terdapat beberapa perusahaan yang menjadi de-listing. Perusahaan dapat de-listing dari Bursa Efek Indonesia (BEI) disebabkan 
karena perusahaan tersebut berada pada kondisi financial distress atau sedang mengalami kesulitan keuangan (Pranowo, 2010).

Financial distress merupakan kondisi dimana perusahaan menghadapi masalah kesulitan keuangan. Financial distress memiliki hubungan erat dengan kebangkrutan pada suatu perusahaan karena financial distress merupakan tahap dimana kondisi keuangan perusahaan mengalami penurunan sebelum terjadinya kebangkrutan. Suatu perusahaan dapat dikategorikan sedang mengalami financial distress jika perusahaan tersebut memiliki kinerja yang menunjukkan laba operasi, laba bersih, dan nilai buku ekuitas yang semua bernilai negatif, serta perusahaan yang melakukan merger (Brahmana, 2007). Laporan keuangan dapat dijadikan dasar untuk mengukur kondisi financial distress suatu perusahaan melalui analisis laporan keuangan dengan menggunakan rasio-rasio keuangan yang ada.

Menurut Rahmy (2015) penyebab financial distress ada yang dari internal dan eksternal. Faktor internal perusahaan lebih bersifat mikro yang meliputi kesulitan arus kas, besarnya jumlah hutang dan mengalami kerugian dalam kegiatan operasional perusahaan selama beberapa tahun. Faktor eksternal perusahaan lebih bersifat makro dimana cakupannya lebih luas. Selain itu, faktor eksternal bisa berupa kebijakan pemerintah yang bisa menambah beban usaha yang ditanggung perusahaan, misalnya tarif pajak yang meningkat bisa menambah beban perusahaan.

Variabel yang digunakan untuk memprediksi financial distress adalah rasio likuiditas, rasio profitabilitas, rasio leverage, operating capacity, dan biaya agensi manajerial. Rasio-rasio tersebut dianggap dapat menunjukkan kinerja keuangan dan efisiensi perusahaan secara umum untuk memprediksi terjadinya financial distress. Indikator kinerja keuangan yang pertama yaitu rasio likiuditas. Menurut Brigham (2010) rasio likuiditas merupakan rasio yang menunjukan hubungan antara kas dan aktiva lancar lainnya dari sebuah perusahaan dengan kewajiban lancarnya. Rasio likuiditas yang biasa dipakai adalah current ratio yang merupakan rasio yang menunjukkan kemampuan perusahaan dalam memenuhi kewajiban finansial jangka pendeknya dengan menggunakan aktiva lancarnya (Triwahyuningtias, 2012). Hasil penelitian yang dilakukan oleh Almilia (2003) menunjukkan bahwa current ratio memiliki pengaruh negatif untuk memprediksi kondisi financial distress suatu perusahaan. Hal ini menunjukkan bahwa semakin tinggi kemampuan perusahaan memenuhi kewajiban jangka pendeknya, maka semakin kecil kemungkinan terjadinya financial distress.

Dalam penelitian ini rasio profitabilitas diukur dengan menggunakan Return on Asset (ROA) digunakan untuk mengukur efektivitas perusahaan di dalam menghasilkan keuntungan dengan memanfaatkan aktiva yang dimilikinya (Ang, 1997). Dalam penelitian Andre (2013) menunjukkan bahwa profitabilitas memiliki pengaruh negatif terhadap financial distress. Hal ini menunjukkan tidak adanya efektivitas dari penggunaan aset perusahaan untuk menghasilkan laba bersih, sehingga apabila profitabilitas suatu perusahaan terus menurun dan bahkan berjumlah negatif, maka kemungkinan perusahaan mengalami kebangkrutan akan semakin besar dan dapat menyebabkan financial distress.

Rasio leverage yang diukur dengan menggunakan debt to asset ratio (DAR) yaitu total hutang dibagi dengan total aktiva. Penelitian yang dilakukan oleh Hanifah (2013) menunjukkan bahwa DAR berpengaruh positif terhadap financial distress. Hal ini menunjukkan bahwa semakin besar kegiatan perusahaan yang dibiayai oleh utang, semakin besar pula kemungkinan terjadinya kondisi financial distress, karena semakin besar kewajiban perusahaan untuk membayar utang tersebut.

Indikator kinerja keuangan selanjutnya adalah rasio aktivitas. Rasio ini dihitung dengan total asset turnover (TAT) yaitu dengan membandingkan total penjualan dengan total asset yang dimiliki perusahaan. Menurut penelitian yang telah dilakukan oleh 
Hanifah (2013) menyebutkan bahwa rasio TAT memiliki pengaruh negatif terhadap financial distress. Hal ini berarti semakin tinggi rasio TAT, semakin rendah kemungkinan terjadinya financial distress.

Indikator penelitian selanjutnya yaitu biaya agensi manajerial yang meliputi pengeluaran yang dilakukan oleh stakeholders untuk memonitor dan memberikan insentif kepada manajemen atas kinerja yang dicapai. Peningkatan biaya agensi manajerial secara kontinyu dapat membebani keuangan perusahaan dan mengakibatkan terjadinya financial distress.

\section{REVIEW LITERATUR DAN HIPOTESIS}

\section{Landasan Teori}

\section{Financial Distress}

Financial distress merupakan kondisi dimana keuangan perusahaan dalam keadaan tidak sehat atau krisis. Financial distress dapat disebabkan oleh faktor internal dan eksternal perusahaan. Faktor internal di antaranya kesulitan arus kas, besarnya jumlah utang, kerugian dalam kegiatan operasional perusahaan selama beberapa tahun. Faktor eksternalnya adalah dapat beruapa kenaikan tingkat bunga pinjaman.

Menurut Platt (2002) dalam Hanifah (2013) financial distress mendefinisikan sebagai tahap penurunan kondisi keuangan yang terjadi sebelum terjadinya kebangkrutan ataupun likuidasi. Menurut Wruck (1990) dalam Hidayat (2013) financial distress merupakan suatu keadaan dimana arus kas operasi tidak cukup untuk memenuhi kewajibankewajiban lancarnya, seperti hutang dagang ataupun biaya bunga. Suatu perusahaan mengalami kondisi financial distress terlebih dahulu, sebelum akhirnya perusahaan tersebut mengalami kebangkrutan, hal ini disebabkan karena pada saat tersebut keadaan keuangan yang terjadi di perusahaan dalam keadaan yang krisis, dimana dalam keadaan seperti ini dapat dikatakan bahwa perusahaan mengalami penurunan dana dalam menjalankan usahanya yang dapat disebabkan karena adanya penurunan dalam pendapatan dari hasil penjualan atau hasil operasi yang dilakukan oleh perusahaan untuk mendapatkan laba, namun pendapatan atau hasil yang diperoleh tidaklah sebanding dengan kewajiban-kewajiban atau hutang yang banyak dan telah jatuh tempo.

\section{Likuiditas}

Brigham (2010) menyatakan bahwa rasio likuiditas merupakan rasio yang menunjukkan hubungan antara kas dan aktiva lancar lainnya dari sebuah perusahaan dengan kewajiban lancarnya. Menurut Deanta (2009) rasio likuiditas merupakan rasio yang digunakan untuk mengukur kemampuan perusahaan dalam memenuhi hutang lancar. Likuiditas perusahaan menunjukkan kemampuan perusahaan dalam mendanai operasional perusahaan dan melunasi kewajiban jangka pendek perusahaan (Widarjo, 2009).

Menurut Hendra (2009) rasio likuiditas adalah rasio yang mengukur kemampuan perusahaan dalam memenuhi kewajiban jangka pendeknya yang telah jatuh tempo. Apabila suatu perusahaan memiliki hutang yang banyak, maka perusahaan memiliki kewajiban yang lebih tinggi untuk dilunasi. Jika suatu perusahaan dapat mendanai dan melunasi hutang jangka pendeknya secara baik, maka potensi perusahaan mengalami financial distress akan semakin kecil.

\section{Profitabilitas}

Menurut Kasmir (2013) rasio profitabilitas merupakan rasio untuk menilai kemampuan perusahaan dalam mencari keuntungan atau laba dalam 
suatu periode tertentu. Dikatakan perusahaan profitabilitas baik apabila mampu memenuhi target laba yang telah ditetapkan dengan menggunakan aktiva atau modal yang dimilikinya. Menurut Deanta (2009) rasio profitabilitas adalah rasio yang mengukur seberapa besar kemampuan perusahaan memperoleh laba baik dalam hubungannya dengan penjualan, aset, laba, maupun modal sendiri.

Rasio profitabilitas adalah rasio yang digunakan untuk mengukur efektifitas manajemen berdasarkan hasilpengambilan yang dihasilkan dari penjualan dan investasi (Weston, 1995 dalam Widarjo, 2009). Profitabilitas adalah kemampuan manajemen dalam memperoleh laba. Laba terdiri dari laba kotor, laba operasi, dan laba bersih. Agar dapat memperoleh laba di atas rata-rata, manajemen harus mampu meningkatkan pendapatan (revenue) dan mengurangi semua beban (expense) atas pendapatan. Manajemen harus memperluas pangsa pasar dengan tingkat harga yang menguntungkan dan menghapuskan aktivitas yang tidak bernilai tambah (Darsono, 2009).

\section{Leverage}

Rasio leverage adalah rasio yang digunakan untuk mengukur sejauh mana aktiva perusahaan dibiayai dengan utang. Artinya berapa besar beban utang yang ditanggung perusahaan dibandingkan dengan aktivanya. Dalam arti luas rasio solvabilitas digunakan untuk mengukur kemampuan perusahaan untuk membayar seluruh kewajibannya, baik jangka pendek maupun jangka panjang (Kasmir, 2013).

Rasio yang juga sering disebut sebagai rasio solvabilitas ini, merupakan rasio yang memperlihatkan proporsi seluruh aktiva perusahaan yang didanai oleh hutang (Fraser, 2008). Dengan kata lain menunjukkan seberapa besar aktiva perusahaan yang dibiayai oleh hutang atau seberapa besar hutang perusahaan berpengaruh terhadap pengelolaan aktiva. Menurut Widarjo (2009), rasio leverage berfungsi untuk mengukur kemampuan suatu perusahaan dalam memenuhi kewajiban-kewajibannya, baik itu dalam jangka pendek maupun jangka panjang jika suatu saat perusahaan tersebut akan dilikuidasi.

\section{Operating Capacity}

Operating capacity merupakan rasio yang mengukur kemampuan perusahaan dalam mengelola aset-asetnya untuk keperluan operasi perusahaan. Jika aset perusahaan tidak bisa dimaksimalkan penggunaannya, maka pendapatan perusahaan juga tidak bisa maksimal, dan akibatnya kemungkinan perusahaan mengalami kesulitan keuangan atau financial distress adalah semakin besar (Hidayat, 2013).

Operating capacity diproksikan dengan total asset turnover atau rasio perputaran total aktiva. Rasio perputaran total aktiva yang tinggi menunjukkan semakin efektif perusahaan dalam penggunaanaktivanyauntukmenghasilkan penjualan (Hanifah, 2013).

\section{Biaya Agensi Manajerial}

Biaya agensi manajerial adalah biaya yang dikeluarkan oleh pemilik untuk mengatur dan mengawasi kinerja para manajer sehingga mereka bekerja untuk kepentingan perusahaan (Fadhilah, 2013). Jensen (1976) menyebutkan 3 jenis biaya agensi yang meliputi monitoring cost, bonding cost, dan residual losses.

Biaya agensi manajerial muncul akibat adanya pemisahan pengendalian dan kepemilikan. Pelaksanaan corporate governance yang buruk dapat meningkatkan biaya agensi manajerial dan menyebabkan inefisiensi ekonomi pada perusahaan. Manajer yang merupakan agen pemegang saham cenderung menggunakan sumber daya perusahan secara eksploitatif untuk memenuhi 
tujuan mereka. Penggunaan sumber daya secara besar-besaran oleh manajer tidak menjamin tercapainya kinerja yang baik dan memungkinkan terjadinya moral hazard. Selain itu, apabila penggunaan sumber daya berlebihan tidak seimbang dengan peningkatan kinerja perusahaan dapat menyebabkan stabilitas perusahaan terganggu (Fadhilah, 2013).

\section{Hipotesis}

\section{Pengaruh Negatif Likuiditas terhadap} Financial Distress

Likuiditas perusahaan menunjukkan kemampuan perusahaan dalam mendanai operasional perusahaan dan melunasi kewajiban jangka pendek perusahaan (Widarjo, 2009). Rasio likuiditas yang biasa dipakai adalah rasio lancar (current ratio) yaitu rasio yang menunjukkan kemampuan perusahaan untuk memenuhi kewajiban jangka pendeknya dengan menggunakan aktiva lancarnya. Dari sudut pandang kreditor jangka pendek, semakin tinggi rasio lancar perusahaan, maka semakin besar pula perlindungannya. Apabila perusahaan mampu mendanai dan melunasi kewajiban jangka pendeknya dengan baik, maka potensi perusahaan mengalami financial distress akan semakin kecil. Dengan demikian, likuiditas berpengaruh negatif terhadap financial distress. Berdasarkan uraian di atas, maka dapat dirumuskan hipotesis sebagai berikut:

\section{H1 :Terdapat Pengaruh Negatif Likuiditas terhadap Financial Distress.}

\section{Pengaruh Negatif Profitabilitas terhadap Financial Distress}

Menurut Ardiyanto (2011) rasio profitabilitas merupakan rasio yang digunakan untuk mengukur kemampuan perusahaan dalam memperoleh laba atau keuntungan. Di dalam penelitian ini profitabilitas diproksikan dengan ROA. Profitabilitas dengan proksi ROA menunjukkan keseluruhan aktiva yang dipergunakan untuk operasi perusahaan mampu memberikan laba bagi perusahaan. Semakin tinggi laba yang dihasilkan, maka semakin tinggi pula ROA. Hal itu berarti bahwa perusahaan semakin efektif dalam penggunaan aktiva untuk menghasilkan keuntungan sehingga kemungkinan terjadinya financial distress dalam perusahaan semakin kecil. Dengan demikian, profitabilitas berpengaruh negatif terhadap financial distress. Berdasarkan uraian diatas, maka dapat dirumuskan hipotesis sebegai berikut:

\section{H2 :Terdapat Pengaruh Negatif Profitabilitas terhadap Financial Distress.}

\section{Pengaruh Positif Leverage terhadap Financial Distress}

Menurut Sigit (2008) dalam Widarjo (2009) leverage timbul akibat dari aktivitas penggunaan dana perusahaan yang berasal dari pihak ketiga dalam bentuk hutang. Penggunaan sumber dana ini akan berakibat pada timbulnya kewajiban bagi perusahaan untuk mengembalikan pinjaman beserta dengan bunga pinjaman yang timbul. Apabila keadaan ini tidak diimbangi dengan pemasukan perusahaan yang baik, besar kemungkinan perusahaan dengan mudah mengalami financial distress. Apabila suatu perusahaan pembiayaannya lebih banyak menggunakan utang, maka hal ini berisiko akan terjadi kesulitan pembayaran dimasa yang akan datang akibat utang lebih besar dari aset yang dimiliki. Jika keadaan ini tidak dapat diatasi dengan baik, maka potensi terjadinya financial distress pun semakin besar (Hanifah, 2013).

Rasio leverage menekankan pada peran penting pendanaan hutang bagi perusahaan dengan menunjukkan persentase aktiva perusahaan yang didukung oleh pendanaan hutang. Adapun dalam penelitian ini leverage diukur 
dengan menggunakan total debt to asset ratio (DAR). Total Debt to Asset Ratio (DAR) merupakan rasio yang digunakan untuk mengukur bagian aktiva yang digunakan untuk menjamin keseluruhan kewajiban atau hutang yang dimiliki perusahaan.

Semakin besar pendanaan perusahaan yang berasal dari hutang, maka akan semakin besar pula kemungkinan perusahaan tersebut mengalami financial distress, hal itu dikarenakan semakin besar kewajiban perusahaan untuk melunasi hutang tersebut. Dengan demikian, leverage berpengaruh positif terhadap financial distress. Berdasarkan uraian di atas, maka dapat dirumuskan hipotesis sebagai berikut:

\section{H3 :Terdapat Pengaruh Positif Leverage terhadap Financial Distress.}

\section{Pengaruh Negatif Operating Capacity terhadap Financial Distress}

Operating capacity merupakan rasio yang mengukur kemampuan perusahaan dalam mengelola aset-asetnya untuk keperluan operasi perusahaan. Jika aset perusahaan tidak dapat dimaksimalkan penggunaannya, maka pendapatan perusahaan juga tidak bisa maksimal, dan akibatnya kemungkinan perusahaan mengalami kesulitan keuangan atau financial distress adalah semakin besar (Hidayat, 2013).

Operating capacity diproksikan dengan total asset turnover atau rasio perputaran total aktiva. Rasio perputaran total aktiva yang tinggi menunjukkan semakin efektif perusahaan dalam penggunaan aktivanya untuk menghasilkan penjualan (Hanifah, 2013). Semakin baik kinerja keuangan yang dicapai oleh perusahaan sehingga kemungkinan terjadinya financial distress semakin kecil. Dengan demikian, operating capacity berpengaruh negatif terhadap financial distress. Berdasarkan uraian di atas, maka dapat dirumuskan hipotesis sebagai berikut:

H4:Terdapat Pengaruh Negatif operating Capacity terhadap Financial Distress.

\section{Pengaruh Positif Biaya Agensi Manajerial terhadap Financial Distress}

Biaya agensi manajerial adalah biaya yang dikeluarkan oleh pemilik untuk mengatur dan mengawasi kinerja para manajer, sehingga mereka bekerja untuk kepentingan perusahaan (Fadhilah, 2013). Biaya agensi manajerial muncul akibat adanya pemisahan pengendalian dan kepemilikan. Pelaksanaan corporate governance yang buruk dapat meningkatkan biaya agensi manajerial dan menyebabkan inefisiensi ekonomi pada perusahaan.

Dalam penelitian ini pengukuran biaya agensi manajerial berdasarkan rasio beban administrasi dan umum. Apabila perusahaan memiliki biaya agensi manajerial yang besar, maka di dalamnya terdapat manajer perusahaan yang cenderung menggunakan sumber daya perusahaan secara eksploitatif untuk memenuhi tujuan mereka. Apabila hal ini terjadi secara terus menerus, maka dapat menyebabkan ketidakstabilan sumber daya perusahaan dan dapat menyebabkan keadaan keuangan menurun dan meningkatkan terjadinya financial distress (Pramuditya, 2014). Dengan demikian, biaya agensi manajerial berpengaruh positif terhadap financial distress. Berdasarkan uraian di atas, maka dapat dirumuskan hipotesis sebagai berikut:

H5 :Terdapat Pengaruh Positif Biaya Agensi Manajerial Terhadap Financial Distress. 


\section{Model Penelitian}

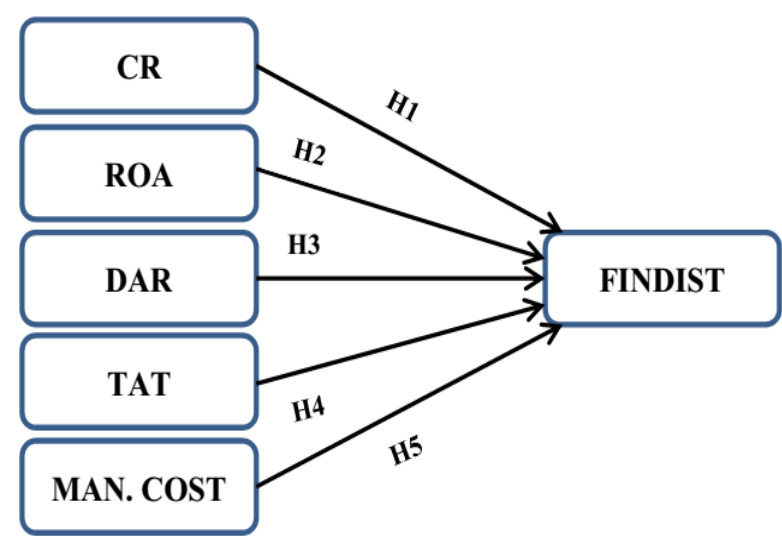

Gambar 2.1. Model Penelitian

\section{Populasi dan Sampel}

Populasi adalah wilayah generalisasi yang terdiri atas obyek atau subyek yang mempunyai kualitas dan karakteristik tertentu yang ditetapkan oleh peneliti untuk mempelajari dan kemudian ditarik kesimpulannya (Sugiyono, 2012). Populasi yang diambil dalam penelitian ini adalah perusahaan manufaktur yang sudah dan masih terdaftar dalam Bursa Efek Indonesia periode 2015-2017.

Sampel merupakan beberapa obyek yang akan diteliti dari seluruh objek penelitian yang dianggap mewakili. Dalam penelitian ini, pengambilan sampel menggunakan teknik purposive sampling yang membatasi objek penelitian pada kriteria-kriteria tertentu.

Kriteria yang digunakan dalam pemilihan sampel perusahaan yang mengalami financial distress adalah sebagai berikut:

1. Perusahaan manufaktur yang sudah dan masih tercatat di Bursa Efek Indonesia (BEI) pada periode penelitian 2015-2017.

2. Perusahan manufaktur yang mempublikasikan laporan keuangan perusahaan pada tahun 2015-2017.

3. Perusahaan yang mengalami laba bersih operasi bernilai negatif secara dua tahun berturut-turut sebelum periode penelitian tahun 2015-2017.

4. Perusahaan yang menyampaikan data secara lengkap periode pengamatan tahun 2015-2017 berkaitan dengan variabel likuiditas, profitabilitas, leverage, operating capacity, dan biaya agensi manajerial.

\section{Variabel Penelitian}

\section{Variabel Dependen}

Variabel terikat dalam penelitian ini adalah financial distress atau permasalahan keuangan yang terjadi pada perusahaan. Penelitian ini mendefinisikan perusahaan yang mengalami financial distress mengacu pada penelitian yang dilakukan oleh Fadhilah (2013) yaitu perusahaan yang memiliki laba bersih negatif dalam satu periode pelaporan.

\section{Variabel Independen}

\section{a. Likuiditas}

Brigham (2010) menyatakan bahwa rasio likuiditas merupakan rasio yang menunjukkan hubungan antara kas dan aktiva lancar lainnya dari sebuah perusahaan dengan kewajiban lancarnya. Dalam penelitian ini, likuiditas diproksikan dengan rasio lancar atau Current Ratio (CR). Rasio lancar merupakan rasio untuk mengukur kemampuan perusahaan dalam membayar kewajiban jangka pendek atau utang yang segera jatuh tempo pada saat ditagih secara keseluruhan.

\section{b. Profitabilitas}

Menurut Kasmir (2013) rasio profitabilitas atau rentabilitas merupakan rasio untuk menilai kemampuan perusahaan dalam mencari keuntungan atau laba dalam suatu periode tertentu. Dalam penelitian ini, profitabilitas diproksikan dengan Return on Asset (ROA). ROA dipergunakan untuk mengetahui kemampuan perusahaan menghasilkan laba bersih melalui penggunaan aset. 


\section{c. Leverage}

Rasio leverage adalah rasio yang digunakan untuk mengukur sejauh mana aktiva perusahaan dibiayai dengan utang. Artinya berapa besar beban utang yang ditanggung perusahaan dibandingkan dengan aktivanya. Dalam arti luas rasio leverage digunakan untuk mengukur kemampuan perusahaan untuk membayar seluruh kewajibannya, baik jangka pendek maupun jangka panjang (Kasmir, 2013). Dalam penelitian ini, leverage diproksikan dengan Debt to Asset Ratio (DAR). DAR merupakan rasio utang yang digunakan untuk mengukur perbandingan antara total utang dengan total aktiva.

\section{d. Operating Capacity}

Operating capacity merupakan rasio yang mengukur kemampuan perusahaan dalam mengelola asetasetnya untuk keperluan operasi perusahaan.Jikaasetperusahaantidak bisa dimaksimalkan penggunaannya, maka pendapatan perusahaan juga tidak dapat maksimal, dan akibatnya kemungkinan perusahaan mengalami kesulitan keuangan atau financial distress adalah semakin besar (Hidayat, 2013). Dalam penelitian ini, operating capacity diproksikan dengan Total Asset Turnover (TAT) atau rasio perputaran total aktiva.

\section{e. Biaya Agensi Manajerial}

Biaya agensi manajerial adalah biaya yang dikeluarkan oleh pemilik untuk mengatur dan mengawasi kinerja para manajer, sehingga mereka bekerja untuk kepentingan perusahaan (Fadhilah, 2013).

\section{Teknik Analisis Data}

\section{Analisis Deskriptif}

Analisis statisik deskriptif adalah statistik yang digunakan untuk menganalisis data dengan cara mendeskripsikan atau menggambarkan data yang telah terkumpul sebagaimana adanya tanpa bermaksud membuat kesimpulan yang berlaku untuk umum atau generalisasi (Sugiyono, 2012). Analisis statistik deskriptif merupakan metode-metode statistik yang berfungsi untuk menggambarkan data yang telah dikumpulkan. Suatu data dapat dideskripsikan melalui mean, standar deviasi, varian, maksimum, minimum, sum, range, skewness, dan kurtosis (Ghozali, 2011).

\section{Uji Multikolinieritas}

Uji multikolinieritas bertujuan untuk mengetahui ada tidaknya hubungan antara variabel independen atau bebas. Pengujian ini dilakukan sebagai syarat digunakannya analisis regresi. Analisis regresi yang baik adalah regresi yang terbebas dari masalah multikolinieritas. Uji multikolinieritas dapat dilakukan dengan melihat nilai tolerance dan nilai Variance Inflation Factor (VIF). Gejala multikolinieritas tidak terjadi apabila nilai VIF tidak lebih besar dari 10 serta nilai tolerance lebih besar dari 0,10 (Ghozali, 2011).

\section{Uji Regresi Logistik}

Pengujian hipotesis dalam penelitian ini bertujuan untuk mengetahui seberapa besar pengaruh variabel independen yang dimasukkan dalam model terhadap variabel dependen. Metode analisis yang digunakan untuk menguji hipotesis dalam penelitian ini adalah regresi logistik (logistic regression). Regresi logistik adalah regresi yang digunakan untuk menguji apakah probabilitas terjadinya variabel dependen dapat diprediksi oleh variabel bebasnya (variabel independen). Model regresi logistik yang akan digunakan untuk menguji hipotesis adalah sebagai berikut:

FINDIST $=a+\beta 1 C R+\beta 2 R O A+\beta 3 D A R$ $+\beta 4$ TAT + 55 MANAG.COST 
Keterangan:

FINDIST: Financial Distress

a : Konstanta

$\beta 1$ : Koefisien CR

$\beta 2$ : Koefisien ROA

$\beta 3$ : Koefisien DAR

B4: Koefisien TAT

$\beta 5$ : Koefisien MANAG. COST

\section{Uji Kelayakan Model}

a. Uji Hosmer and Lemeshow's Goodness of Fit

Hosmer and Lemeshow's Goodness of Fit menguji hipotesis nol bahwa data empiris cocok atau sesuai dengan model atau tidak ada perbedaan antara model dengan data, sehingga model dapat dikatakan fit. Pengujian kelayakan model regresi logistik dilakukan dengan menggunakan Goodness of fit test yang diukur dengan nilai Chi-Square pada bagian bawah uji Hosmer and Lemeshow.

Dasar pengambilan keputusan adalah dengan memperhatikan nilai goodness of fit test yang diukur dengan nilai chi square pada bagian bawah uji Hosmer and Lemeshow: Jika probabilitas $>5 \%$, maka hipotesis diterima

Jika probabilitas $<5 \%$, maka hipotesis ditolak

\section{b. Uji Likelihood}

Statistik yang digunakan berdasarkan pada fungsi Likelihood.

Likelihood L dari model adalah probabilitas bahwa model yang dihipotesiskan menggambarkan data input. Untuk menguji hipotesis nol dan alternatif, L ditransformasikan -2LogL. Penurunan log Likelihood menunjukkan model regresi yang lebih baik. c. Uji Cox and Snell $R$ Square dan Nagelkerke's $R$ Square

Nilai Nagelkerke's $R$ Square dapat diinterprestasikan seperti nilai $\mathrm{R}^{2}$ pada multiple regression dengan tujuan mengetahui seberapa besar kombinasi variabel independen mampu menjelaskan variabel dependen. Nagelkerke's $R$ Square merupakan modifikasi dari koefisien Cox dan Snell's. Nagelkerke's $R$ Square dihitung dengan cara membagi nilai Cox dan Snell's $R^{2}$ dengan nilai maksimumnya. Cox dan Snell's $R$ Square merupakan ukuran yang mencoba meniru ukuran $\mathrm{R}^{2}$ pada multiple regression yang didasarkan pada teknik estimasi Likelihood dengan nilai maksimum kurang dari satu.

\section{HASIL PENELITIAN DAN PEMBAHASAN}

\section{Deskripsi Data}

Penelitian ini menggunakan sumber data sekunder. Data yang digunakan, yaitu Current Ratio, Return on Asset, Debt to Asset Ratio, Total Asset Turnover, dan Biaya Agensi Manajerial perusahaan. Data diperoleh dari laporan keuangan tahunan yang diakses melalui situs resmi Bursa Efek Indonesia. Populasi dalam penelitian ini adalah seluruh perusahaan manufaktur yang terdaftar di Bursa Efek Indonesia pada tahun 2015-2017. Dari populasi tersebut kemudian dilakukan pengambilan sampel dengan metode purposive sampling. Sampel yang digunakan berjumlah 84 perusahaan. Kelompok perusahaan yang mengalami financial distress sebanyak 42 perusahaan. Kelompok perusahaan yang tidak mengalami financial distress sebanyak 42 perusahaan. 
2. Statistik Deskriptif

Tabel 4.1. Statistik Deskriptif Seluruh Perusahaan Dalam Sampel

\begin{tabular}{lrrrrr}
\hline & $\mathrm{N}$ & Minimum & Maximum & \multicolumn{1}{c}{ Mean } & Std. Deviation \\
\hline LIQUID & 84 & 0,0337 & 15,1646 & 2,215920 & 2,3461251 \\
\hline PROFIT & 84 & $-0,5485$ & 0,7160 & $-0,006896$ & 0,1308772 \\
\hline LEV & 84 & 0,1110 & 2,7669 & 0,623735 & 0,5127223 \\
\hline OPE_CAP & 84 & 0,0435 & 3,0573 & 0,795208 & 0,5658175 \\
\hline MAN_COST & 84 & 0,0073 & 1,3387 & 0,124576 & 0,2151465 \\
\hline
\end{tabular}

Hasil statistik deskriptifmenunjukkan unit observasi sejumlah 84 . Berdasarkan hasil statistik deskriptif yang ditunjukkan dalam tabel 4.1, dapat diketahui gambaran dari masing-masing variabel independen sebagai berikut:

\section{a. Current Ratio (CR)}

Hasil pengujian statistik deskriptif pada tabel 4.1 memperlihatkan bahwa data current ratio memiliki nilai terendah sebesar 0,0337 dan tertinggi sebesar 15,1646. Current ratio pada sampel penelitian ini berkisar antara 0,0337 sampai dengan 15,1646 yang memiliki ratarata sebesar 2,215920 dan standar deviasi sebesar 2,3461251.

\section{b. Return On Asset (ROA)}

Pengujian statistik deskriptif data ROA menunjukkan bahwa variabel tersebut memiliki nilai terendah $-0,5485$ dan nilai tertinggi 0,7160 . Nilai ROA pada sampel penelitian ini berkisar antara $-0,5485$ hingga 0,7160 dengan ratarata sebesar $-0,006896$ dan standar deviasi sebesar 0,1308772.

\section{c. Debt to Asset Ratio (DAR)}

Hasil pengujian statistik deskriptif pada tabel 4.1 memperlihatkan bahwa data Debt to Asset Ratio memiliki nilai terendah sebesar 0,1110 dan tertinggi sebesar 2,7669. Debt to Asset Ratio pada sampel penelitian ini berkisar antara 0,1110 sampai dengan 2,7669 yang memiliki rata-rata sebesar
0,623735 dan standar deviasi sebesar 0,5127223 .

\section{d. Total Asset Turnover (TAT)}

Hasil statistik deskriptif menunjukkan data total asset turnover memiliki nilai terendah sebesar 0,0435 dan nilai tertinggi sebesar 3,0573. Oleh sebab itu nilai total asset turnover pada sampel penelitian ini berkisar antara 0,0435 hingga 3,0573 dengan rata-rata sebesar 0,795208 dan standar deviasi sebesar 0,5658175.

\section{e. Biaya Agensi Manajerial}

Hasil statistik deskriptif menunjukkan biaya agensi manajerial memiliki nilai terendah sebesar 0,0073 dan nilai tertinggi sebesar 1,3387. Oleh sebab itu, nilai biaya agensi manajerial pada sampel penelitian ini berkisar antara 0,0073 hingga 1,3387 dengan rata-rata sebesar 0,124576 dan standar deviasi sebesar 0,2151465.

Sementara itu tabel 4.2 dan tabel 4.3 akan menjelaskan gambaran umum penelitian secara khusus, yaitu statistik deskriptif perusahaan yang mengalami kondisi financial distress dan perusahaan yang tidak mengalami kondisi financial distress. Berikut adalah tabel 4.2 dan tabel 4.3.

Tabel 4.2. Statistik Deskriptif

Perusahaan Yang Mengalami Financial Distress

\begin{tabular}{|c|c|c|c|c|c|}
\hline & $\mathrm{N}$ & Minimum & Maximum & Mean & itd. De \\
\hline QUIID & 42 & & & & \\
\hline ROFIT & 42 & $-0,5485$ & & $-0,060674$ & \\
\hline EV & 42 & 0,1227 & 2,7669 & 0,859676 & 0,612 \\
\hline PE CAP & 42 & 0,0435 & 2,0255 & 0,644745 & 0,5072443 \\
\hline AAN_COST & & 0,0073 & 1,3387 & 0,183112 & 0,2912297 \\
\hline
\end{tabular}


Tabel 4.3. Statistik Deskriptif Perusahaan Yang Tidak Mengalami Financial Distress

\begin{tabular}{lrrrrr}
\hline & $\mathrm{N}$ & Minimum & Maximum & Mean & Std. Deviation \\
\hline LIQUID & 42 & 0,6486 & 15,1646 & 2,811938 & 2,5842440 \\
\hline PROFIT & 42 & 0,0004 & 0,1751 & 0,046881 & 0,0488310 \\
\hline LEV & 42 & 0,1110 & 0,8197 & 0,389793 & 0,2107692 \\
\hline OPE_CAP & 42 & 0,1863 & 3,0573 & 0,45671 & 0,5868800 \\
\hline MAN_COST & 42 & 0,0104 & 0,2196 & 0,060040 & 0,4432465 \\
\hline
\end{tabular}

Hasil statistik deskriptifmenunjukkan bahwa unit observasi perusahaan yang mengalami financial distress sebanyak 42. Unit observasi perusahaan yang tidak mengalami financial distress sebanyak 42.

\section{a. Current Ratio}

Pada tabel 4.2 dan tabel 4.3 menunjukkan bahwa dalam sampel penelitian rata-rata nilai Current Ratio (CR) perusahaan yang mengalami financial distress sebesar 1,619902 dan perusahaan yang tidak mengalami financial distress sebesar 2,811938. Data penelitian ini menunjukkan bahwa perusahaan yang mengalami financial distress cenderung memiliki nilai Current Ratio (CR) lebih rendah dibandingkan perusahaan yang tidak mengalami financial distress.

\section{b. Return On Asset}

Pada tabel 4.2 hasil statistik deskriptif menunjukkan bahwa ratarata nilai Return on Asset (ROA) perusahaan yang mengalamifinancial distress -0,060674. Nilai tersebut lebih tinggi dibandingkan dengan perusahaan yang tidak mengalami financial distress sebesar 0,046881. Data penelitian ini menunjukkan perusahaan yang mengalamifinancial distress cenderung memiliki nilai ROA lebih tinggi dibandingkan perusahaan yang tidak mengalami financial distress.

\section{c. Debt to Asset Ratio}

Debt to Asset Ratio pada tabel 4.2 dan tabel 4.3 menunjukkan bahwa dalam sampel penelitian ratarata nilai Debt to Asset Ratio (DAR) perusahaan yang mengalamifinancial distress sebesar 0,857676 dan perusahaan yang tidak mengalami financial distress sebesar 0,389793. Data penelitian ini menunjukkan bahwa perusahaan yang mengalami financial distress cenderung memiliki nilai DAR lebih tinggi dibandingkan perusahaan yang tidak mengalami financial distress.

\section{d. Total Asset Turnover}

Hasil statistik deskriptif pada tabel 4.2 dan tabel 4.3 menunjukkan bahwa rata-rata nilai Total Asset Turnover (TAT) perusahaan yang mengalami financial distress lebih rendah dibandingkan dengan perusahaan yang tidak mengalami financial distress. Dalam data penelitian ini rata-rata nilai TAT perusahaan yang mengalamifinancial distress sebesar 0,644745 dan perusahaan yang tidak mengalami financial distress sebesar 0,945671. Data penelitian ini menunjukkan bahwa perusahaan yang mengalami financial distress cenderung memiliki TAT yang lebih rendah dibandingkan perusahaan yang tidak mengalami financial distress.

\section{e. Biaya Agensi Manajerial}

Pada tabel 4.2 dan tabel 4.3 menunjukkan bahwa dalam sampel penelitian rata-rata biaya agensi manajerial perusahaan yang mengalami financial distress sebesar 0,183112 dan perusahaan yang tidak mengalami financial distress sebesar 0,066040. Data penelitian ini menunjukkan bahwa perusahaan yang mengalami financial distress cenderung memiliki nilai biaya 
agensi manajerial lebih rendah dibandingkan perusahaan yang tidak mengalami financial distress.

\section{Uji Multikolinieritas}

Tabel 4.4. Hasil Uji Multikolinieritas

\begin{tabular}{llll}
\hline Variabel & \multicolumn{2}{l}{ Collinearity Statistics } & Kesimpulan \\
\cline { 2 - 4 } & Tolerance & VIF & Tidak terjadi multikolinearitas \\
\hline LIQUID & 0,796 & 1,256 & Tidak terjadi multikolinearitas \\
\hline PROFIT & 0,738 & 1,355 & Tidak terjadi multikolinearitas \\
\hline LEV & 0,731 & 1,368 & Tidak terjadi multikolinearitas \\
\hline OPE_CAP & 0,836 & 1,196 & Tidak terjadi multikolinearitas \\
\hline MAN_COST & 0,809 & 1,235 & Tidak terjadi multikolinearitas \\
\hline
\end{tabular}

Hasil perhitungan uji multikolinieritas yang ditunjukkan oleh tabel 4.4 memperlihatkan tidak ada variabel independen yang memiliki nilai tolerance kurang dari 0,10. Sementara itu, hasil perhitungan nilai Variance Inflation Factor (VIF) juga menunjukkan tidak ada satupun variabel independen yang memiliki nilai VIF lebih dari 10 . Oleh sebab itu, dapat diambil kesimpulan bahwa dalam model regresi tidak terdapat masalah multikolinieritas antar variabel independen dalam model regresi.

4. Hasil Uji Goodness Fit Model

Tabel 4.5. Hasil Uji Hosmer and Lemeshow Test

\begin{tabular}{llll}
\hline Step & Chi-square & Df & Sig. \\
\hline 1 & 6,538 & 8 & 0,587 \\
\hline
\end{tabular}

Hasil uji Hosmer and Lemeshow pada tabel 4.5 menunjukkan nilai chi square sebesar 6,538 dan nilai signifikansi sebesar 0,587 . Nilai signifikansi yang dihasilkan lebih dari 0,05 , sehingga $\mathrm{H} 0$ diterima atau model yang dihipotesiskan fit dengan data. Oleh sebab itu, tidak terdapat perbedaan antara klasifikasi yang diprediksi dengan klasifikasi yang diamati.
Tabel 4.6. Hasil Uji Log Likelihood Value Blok Pertama

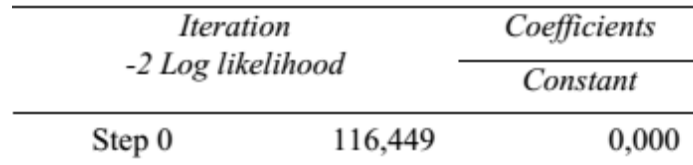

Hasil perhitungan nilai -2 log likelihood memiliki dua nilai, yaitu model yang hanya dimasukkan konstanta saja dan model dengan konstanta serta variabel bebas. Nilai -2 log likelihood yang dimasukkan konstanta saja ditunjukkan oleh blok pertama pada tabel 4.6. Nilai yang dihasilkan sebesar 116,449.

\section{Tabel 4.7. Hasil Uji Log Likelihood} Value Blok Kedua

\begin{tabular}{|c|c|c|c|c|c|c|c|}
\hline \multirow[t]{2}{*}{ Iteration } & \multirow{2}{*}{$\begin{array}{c}-2 \log \\
\text { likelihood }\end{array}$} & \multicolumn{6}{|c|}{ Coefficients } \\
\hline & & Constant & CR & ROA & DAR & TAT & $\begin{array}{c}\text { MANAG. } \\
\text { COST }\end{array}$ \\
\hline 1 & 86,803 & $-0,313$ & $-0,071$ & $-3,126$ & 1,193 & $-0,504$ & 0,837 \\
\hline 2 & 80,568 & $.1,023$ & $\cdot 0,021$ & $-4,982$ & 2,329 & $-0,604$ & 1,838 \\
\hline 3 & 78,355 & $-1,869$ & 0,043 & $.5,646$ & 3,520 & $-0,612$ & 3,524 \\
\hline 4 & 77,876 & $-2,267$ & 0,045 & $-6,172$ & 3,836 & $.0,527$ & 5,912 \\
\hline 5 & 77,826 & $-2,390$ & 0,038 & $-6,268$ & 3,876 & $-0,490$ & 7,151 \\
\hline 6 & 77,826 & $-2,399$ & 0,038 & $-6,275$ & 3,880 & $-0,487$ & 7,250 \\
\hline 7 & 77,826 & $-2,400$ & 0,038 & $-6,275$ & 3,880 & $-0,487$ & 7,250 \\
\hline
\end{tabular}

Perhitungan nilai -2 log likelihood pada blok kedua atau model dengan konstanta dan variabel bebas dapat dilihat hasilnya pada tabel 4.7. Nilai tersebut mengalami penurunan dibandingkan blok pertama, yaitu menjadi 77,826. Dalam penilaian keseluruhan model regresi dengan menggunakan nilai -2 log likehood, jika terjadi penurunan pada nilai blok kedua atau model kedua yang menggunakan konstanta dan variabel bebas dibandingkan nilai blok pertama atau model pertama yang hanya menggunakan konstanta saja, maka dapat disimpulkan bahwa model regresi kedua menjadi lebih baik. 
Tabel 4.8. Hasil Uji Nagelkerke's $R$

\begin{tabular}{cccc}
\multicolumn{4}{c}{ Square } \\
\hline Step & $\begin{array}{c}-2 \text { Log } \\
\text { likelihood }\end{array}$ & $\begin{array}{c}\text { Cox \& Snell } \\
\text { R Square }\end{array}$ & $\begin{array}{c}\text { Nagelkerke } \\
\text { R Square }\end{array}$ \\
\hline 1 & $77,826^{\mathrm{a}}$ & 0,369 & 0,491 \\
\hline
\end{tabular}

Nilai Nagelkerke R Square dari persamaan regresi ditunjukkan pada tabel 4.8. Tabel tersebut menunjukkan pengujian Nagelkerke's $R$ Square memiliki nilai sebesar 0,491 atau 49,1\%. Hasil tersebut menunjukkan bahwa kemampuan variabel independen menjelaskan variabel dependen sebesar 49,1\%. Sementara itu $50,9 \%$ dijelaskan oleh faktor-faktor lain.

\section{Hasil Uji Ketepatan Prediksi Klasifikasi}

Tabel 4.9. Hasil Uji Ketepatan Prediksi Klasifikasi

\begin{tabular}{|c|c|c|c|c|}
\hline \multirow{3}{*}{\multicolumn{2}{|c|}{ Observed }} & \multicolumn{3}{|c|}{ Predicted } \\
\hline & & \multicolumn{2}{|c|}{ Findist } & \multirow{2}{*}{$\begin{array}{l}\text { Percentage } \\
\text { Correct }\end{array}$} \\
\hline & & $\begin{array}{c}\text { Non Financial } \\
\text { Distress }\end{array}$ & $\begin{array}{c}\text { Financial } \\
\text { Distress }\end{array}$ & \\
\hline \multirow[t]{2}{*}{ Findist } & $\begin{array}{l}\text { Non Financial } \\
\text { Distress }\end{array}$ & 35 & 7 & 83,3 \\
\hline & $\begin{array}{l}\text { Financial } \\
\text { Distress }\end{array}$ & 9 & 33 & 78,6 \\
\hline $\begin{array}{l}\text { Overall } \\
\text { Percente }\end{array}$ & & & & 81,0 \\
\hline
\end{tabular}

Ketepatan prediksi klasifikasi digunakan untuk menunjukkan seberapa baik hasil prediksi model. Tabel ketepatan prediksiklasifikasi(tabel4.9)menunjukkan bahwa dari 42 unit observasi yang sesungguhnya tidak mengalami financial distress, diprediksi oleh model tepat 35 unit observasi sebagai tidak mengalami financial distress dan 7 unit observasi sebagai mengalami financial distress. Oleh sebab itu, nilai kebenaran klasifikasi sebesar $83,3 \%$. Sementara itu dari 42 unit observasi yang sesungguhnya mengalami financial distress, diprediksi tepat oleh model 33 unit observasi mengalami financial distress, sedangkan model tidak tepat memprediksi 9 unit observasi tidak mengalami financial distress. Oleh sebab itu nilai kebenaran klasifikasi sebesar $78,5 \%$. Nilai overall percentage sebesar $((35+33) / 84) \times 100 \%=80,9 \%$.

6. Hasil Uji Analisis Regresi Logistik Tabel 4.10. Analisis Regresi Linier Logistik

\begin{tabular}{lccl}
\hline \multicolumn{1}{c}{ Variabel } & B & Sig. & Kesimpulan \\
\hline CR & 0,038 & 0,795 & $\mathrm{H}_{\mathrm{al}}$ Ditolak \\
\hline ROA & $-6,275$ & 0,232 & $\mathrm{H}_{\mathrm{H}_{2}}$ Ditolak \\
\hline DAR & 3,880 & 0,013 & $\mathrm{H}_{3^{3}}$ Diterima \\
\hline TAT & $-0,487$ & 0,484 & $\mathrm{H}_{24}$ Ditolak \\
\hline MANAG.COST & 7,250 & 0,248 & $\mathrm{H}_{25}$ Ditolak \\
\hline Constant & $-2,400$ & 0,052 & \\
\hline
\end{tabular}

Berdasarkan hasil analisis regresi logistik yang ditunjukkan pada tabel 4.10 dapat disimpulkan bahwa penelitian Likuiditas, Profitabilitas, Leverage, Operating Capacity, dan Biaya Agensi Manajerial terhadap Financial Distress ini menghasilkan persamaan matematis sebagai berikut:

FINDIST $=-2,400+0,038 \mathrm{CR}-6,275 \mathrm{ROA}$ $+3,880 \mathrm{DAR}-0,487 \mathrm{TAT}+7,250 \mathrm{MANAG}$. COST

\section{Uji Hipotesis}

\section{a. Pengujian Hipotesis Pertama}

Berdasarkan hasil uji hipotesis pada tabel 4.10, variabel Current Ratio (CR) memiliki koefisien regresi sebesar 0,038 dengan tingkat siginfikansi 0,795 . Tingkat signifikansi Current Ratio (CR) lebih besar dari nilai signifikansi yang telah ditetapkan yaitu 0,05 . Hasil penelitian menunjukkan bahwa variabel likuiditas yang diproksikan dengan Current Ratio tidak berpengaruh terhadap financial distress sehingga hipotesis pertama ditolak.

\section{b. Pengujian Hipotesis Kedua}

Hasil uji hipotesis pada tabel 4.10, variabel Return on Asset (ROA) memiliki koefisien regresi sebesar $-6,275$ dengan tingkat siginfikansi 0,232 . Nilai koefisiensi bersifat negatif 
dan tingkat signifikansi Return on Asset lebih besar darinilai signifikansi yang telah ditetapkan yaitu 0,05 . Hasil penelitian menunjukkan bahwa variabel profitabilitas yang diproksikan dengan Return on Asset (ROA) tidak berpengaruh terhadap financial distress, oleh sebab itu hipotesis kedua ditolak.

\section{c. Pengujian Hipotesis Ketiga}

Variabel Debt to Asset Ratio (DAR) memiliki koefisien sebesar 3,880 dengan tingkat signifikansi 0,013 . Nilai signifikansi menunjukkan lebih kecil dari 0,05, sehingga dapat disimpulkan variabel rasio leverage yang diproksikan dengan Debt to Asset Ratio (DAR) berpengaruh positif terhadap financial distress. Dengan demikian, hipotesis ketiga diterima.

\section{d. Pengujian Hipotesis Keempat}

Hasil pengujian hipotesis menunjukkan variabel Total Asset Turnover (TAT) memiliki koefisien sebesar -0,487 dengan tingkat signifikansi sebesar 0,484. Nilai koefisien bersifat negatif dan tingkat signifikansi lebih besar dari 0,05, sehingga dapat ditarik kesimpulan bahwa operating capacity yang diproksikan dengan Total Asset Turnover (TAT) tidak berpengaruh terhadap financial distress. Dengan demikian, hipotesis keempat ditolak.

\section{e. Pengujian Hipotesis Kelima}

Hasil pengujian hipotesis menunjukkan biaya agensi manajerial memiliki koefisien sebesar 7,250 dengan tingkat signifikansi sebesar 0,248 . Tingkat signifikansi lebih besar dari 0,05 , oleh sebab itu dapat ditarik kesimpulan bahwa biaya agensi manajerial tidak berpengaruh terhadap financial distress, sehingga hipotesis kelima ditolak

\section{Pembahasan}

\section{Pengaruh Negatif Likuiditas terhadap Financial Distresss}

Hasil penelitian menunjukkan variabel likuiditas yang diproksikan dengan current ratio memiliki koefisien regresi sebesar 0,038 dan tingkat signifikansi 0,795 . Nilai signifikansi yang dihasilkan lebih dari 0,05. Hasil penelitian menunjukkan bahwa variabel likuiditas yang diproksikan dengan current ratio tidak berpengaruh terhadap financial distress. Oleh sebab itu hipotesis pertama ditolak.

Financial distress dimulai dari ketidakmampuan perusahaan dalam memenuhi kewajiban-kewajibannya, terutamakewajibanjangkapendek. Current ratio merupakan rasio yang menunjukkan tingkat kemampuan aktiva lancar perusahaan dalam menutupi kewajibankewajiban jangka pendek. Semakin besar perbandingan aktiva lancar dengan utang lancar yang ditunjukkan dengan tingginya current ratio menunjukkan semakin tinggi pula kemampuan perusahaan dalam menutupi kewajiban lancar. Hal ini membuat semakin besar tingkat jaminan atas terbayarnya kewajiban lancar, sehingga probabilitas munculnya financial distress dapat ditekan.

Hasil penelitian ini menunjukkan bahwa current ratio tidak mampu digunakan dalam memprediksi kondisi financial distress karena hasil perhitungan current ratio untuk seluruh sampel penelitian menunjukkan nilai mean lebih kecil dibanding dengan nilai standar deviasinya, yaitu $2,215920<2,3461251$. Hasil tersebut menandakan distribusi variabel likuiditas yang diproksikan dengan current ratio tidak baik, yaitu terdapat kesenjangan antara nilai minimal dan maksimal, sehingga mempengaruhi hasil dari uji hipotesis.

Hapsari (2012) meneliti tentang kekuatan rasio keuangan dalam memprediksi kondisi financial distress 
perusahaan manufaktur di BEI. Penelitian tersebut menunjukkan bahwa current ratio tidak berpengaruh terhadap financial distress. Penelitian yang dilakukan oleh Saleh (2013) juga menunjukkan bahwa current ratio tidak berpengaruh terhadap financial distress.

\section{Pengaruh Negatif Profitabilitas terhadap Financial Distress}

Hasil penelitian variabel Return On Asset (ROA) memiliki koefisien regresi sebesar -6,275 dengan tingkat signifikansi 0,232 . Nilai koefisien bersifat negatif dan tingkat signifikansi Return On Asset lebih besar dari nilai signifikansi yang telah ditetapkan, yaitu 0,05. Hasil penelitian menunjukkan bahwa variabel profitabilitas yang diproksikan dengan Return on Asset tidak berpengaruh terhadap financial distress, oleh sebab itu hipotesis kedua ditolak.

Profitabilitas merupakan rasio yang digunakan untuk mengukur kemampuan perusahaan dalam memperoleh laba atau keuntungan. Profitabilitas dengan proksi ROA yang positif menunjukkan keseluruhan aktiva yang dipergunakan untuk operasi perusahaan mampu memberikan laba bagi perusahaan. Semakin tinggi laba yang dihasilkan, maka semakin tinggi pula ROA. Hal itu berarti bahwa perusahaan semakin efektif dalam penggunaan aktiva untuk menghasilkan keuntungan, sehingga kemungkinan terjadinya financial distress dalam perusahaan semakin kecil.

Hasil penelitian ini menunjukkan bahwa Return On Asset tidak mampu digunakan dalam memprediksi kondisi financial distress, karena hasil perhitungan Return On Asset untuk seluruh sampel penelitian menunjukkan nilai mean lebih kecil dibanding dengan nilai standar deviasinya, yaitu $-0,006896<0,1308772$. Hasil tersebut menandakan distribusi variabel profitabilitas yang diproksikan dengan Return on Asset tidak baik, yaitu terdapat kesenjangan antara nilai minimal dan maksimal, sehingga mempengaruhi hasil dari uji hipotesis.

Penelitian terdahulu oleh Alifiah et al., (2012) yang menyatakan bahwa rasio profitabilitas tidak berpengaruh signifikan terhadap kemungkinan terjadinya financial distress di suatu perusahaan. Hasil penelitian juga menunjukkan hasil yang sama dengan penelitian yang dilakukan oleh Hanifah (2013) yang menyatakan bahwa rasio profitabilitas tidak signifikan dalam mempengaruhi financial distress.

\section{Pengaruh Positif Leverage terhadap Financial Distress}

Hasil penelitian pada variabel financial leverage yang diproksikan dengan debt to asset ratio (DAR) memiliki koefisien regresi sebesar 3,880 dan tingkat signifikansi 0,013 yang menunjukkan bahwa nilai signifikansi lebih kecil dari 0,05 . Oleh sebab itu dapat disimpulkan variabel rasio leverage yang diproksikan dengan debt to asset ratio berpengaruh positif terhadap financial distress, sehingga hipotesis ketiga diterima.

Hasil olah data menunjukkan ada beberapa perusahaan yang mempunyai nilai debt to asset ratio lebih besar dari satu. Hal tersebut dikarenakan jumlah utang yang dimiliki perusahaan tersebut lebih besar dari aset yang dimilikinya. Perusahaan dengan tingkat utang yang terlalu tinggi akan menimbulkan masalah pada kemungkinan terjadinya kesulitan pembayaran pinjaman yang tersisa dan bunga di masa depan. Semakin tinggi nilai debt to asset ratio, maka semakin besar pula resiko yang dihadapi perusahaan, dan sebaliknya. Perusahaan yang mengalami financial distress cenderung mempunyai nilai debt to asset ratio yang lebih tinggi dibandingkan perusahaan yang tidak mengalami financial distress, karena kebanyakan perusahaan yang mengalami financial distress mempunyai tingkat utang yang lebih tinggi. Debt to asset ratio 
dan financial distress memiliki hubungan berbanding lurus. Semakin tinggi debt to asset ratio akan meningkatkan probabilitas financial distress. Hasil pada penelitian ini menunjukkan bahwa debt to asset ratio berpengaruh positif dan signifikan terhadap financial distress.

Hasil penelitian juga sesuai dengan penelitian yang dilakukan oleh Ahmad (2011) yang menyatakan bahwa debt to asset ratio signifikan berpengaruh positif terhadap kemungkinan terjadinya financial distress di suatu perusahaan. Hasil yang sama juga ditunjukkan dalam penelitian yang telah dilakukan oleh Platt (2002) yang menunjukkan bahwa rasio leverage berpengaruh positif dan signifikan terhadap kondisi financial distress.

\section{Pengaruh Negatif Operating Capacity terhadap Financial Distress}

Hasil penelitian menunjukkan variabel total asset turnover memiliki koefisien sebesar -0,487 dengan tingkat signifikansi sebesar 0,484 . Nilai koefisien bersifat negatif dan tingkat signifikansi lebih besar dari 0,05. Oleh sebab itu dapat ditarik kesimpulan bahwa operating capacity yang diproksikan dengan total asset turnover (TAT) tidak berpengaruh terhadap financial distress sehingga hipotesis keempat ditolak.

Perusahaan yang mampu mengelola asetnya secara efisien akan menekan probabilitas financial distress. Efisiensi penggunaan asset dapat ditunjukkan oleh total asset turnover ratio. Rasio ini menganalisis kemampuan aset perusahaan dalam menghasilkan penjualan. Semakin besar rasio total asset turnover menunjukkan semakin tinggi perputaran total aktiva, maka semakin efektif total aktiva dalam menghasilkan penjualan. Tingginya rasio total asset turnover menunjukkan bahwa perusahaan mampu menghasilkan tingkat penjualan tinggi dengan jumlah total aset yang dimiliki.
Penjualan yang tinggi akan meningkatkan laba perusahaan, sehingga tingkat kecukupan dana perusahaan dalam menjalankan operasi akan baik, sehingga tingkat probabilitas munculnya financial distress akan tertekan.

Hasil penelitian menunjukkan operating capacity yang diproksikan dengan total asset turnover tidak berpengaruh terhadap financial distress. Berdasarkan data penelitian terdapat sampel perusahaan yang memiliki total asset turnover tinggi tetapi masuk ke dalam kategori perusahaan yang mengalami financial distress, karena memiliki laba negatif selama dua tahun berturutturut. Perusahaan tersebut berjumlah 14 perusahaan dari 42 perusahaan sampel. Hal tersebut berarti terdapat 33,33\% perusahaan yang memiliki total asset turnover tinggi di atas mean tetapi masuk ke dalam kategori perusahaan yang mengalami financial distress.

Hasil penelitian menunjukkan hasil yang sama dengan penelitian yang dilakukan oleh Nella (2011) yang menyebutkan bahwa total asset turnover tidak signifikan dalam mempengaruhi financial distress di suatu perusahaan.

\section{Pengaruh Positif Biaya Agensi Manajerial terhadap Financial Distress}

Hasil pengujian hipotesis menunjukkan biaya agensi manajerial memiliki koefisien sebesar 7,250 dengan tingkat signifikansi sebesar 0,248 yang mana tingkat signifikansi lebih besar dari 0,05 . Oleh sebab itu, dapat ditarik kesimpulan bahwa biaya agensi manajerial tidak berpengaruh terhadap financial distress, sehingga hipotesis kelima ditolak.

Hasil penelitian ini menunjukkan bahwa biaya agensi manajerial tidak mampu digunakan dalam memprediksi kondisi financial distress, karena hasil perhitungan biaya agensi manajerial untuk 
seluruh sampel penelitian menunjukkan nilai mean lebih kecil dibanding dengan nilai standar deviasinya, yaitu 0,124576 $<0,2151465$. Hasil tersebut menandakan distribusi variabel biaya agensi manajerial tidak baik, yaitu terdapat kesenjangan antara nilai minimal dan maksimal, sehingga mempengaruhi hasil dari uji hipotesis.

\section{KESIMPULAN DAN SARAN}

\section{Kesimpulan}

Berdasarkan hasil penelitian di atas, maka dapat disimpulkan bahwa:

1. Variabel likuiditas yang diproksikan dengan Current Ratio (CR) tidak berpengaruh negatif terhadap financial distress. Hal ini dibuktikan dengan melihat koefisien $\beta$ bernilai positif sebesar 0,038. Hasil uji signifikansi terhadap kondisi financial distress diperoleh nilai sebesar 0,795 dengan tingkat signifikansi lebih besar dibandingkan taraf signifikansi yang ditetapkan $(0,795>0,05)$. Maka dari itu dapat disimpulkan bahwa hipotesis pertama yang menyatakan Current Ratio (CR) berpengaruh negatif terhadap financial distress ditolak.

2. Variabel profitabilitas yang diproksikan dengan Return on Asset (ROA) tidak berpengaruh negatif terhadap financial distress. Hal ini dibuktikan dengan melihat koefisien $\beta$ bernilai negatif sebesar 6,275. Hasil uji signifikansi terhadap kondisi financial distress diperoleh nilai sebesar 0,232 dengan tingkat signifikansi lebih besar dibandingkan taraf signifikansi yang ditetapkan $(0,232>0,05)$. Maka dari itu hipotesis kedua yang menyatakan return on asset berpengaruh negatif terhadap financial distress ditolak.

3. Variabel leverage yang diproksikan dengan Debt to Asset Ratio (DAR) berpengaruh positif terhadap financial distress. Hal ini dibuktikan dengan melihat koefisien $\beta$ bernilai positif sebesar 3,880. Hasil uji signifikansi terhadap kondisi financial distress diperoleh nilai sebesar 0,013 dengan tingkat signifikansi lebih kecil dibandingkan taraf signifikansi yang ditetapkan $(0,013<0,05)$. Maka dari itu hipotesis ketiga yang menyatakan debt to asset ratio berpengaruh positif terhadap financial distress diterima.

4. Variabel operating capacity yang diproksikan dengan Total Asset Turnover (TAT) tidak berpengaruh negatif terhadap financial distress. Hal ini dibuktikan dengan melihat koefisien $\beta$ bernilai negatif sebesar 0,487 . Hasil uji signifikansi terhadap kondisi financial distress diperoleh nilai sebesar 0,484 dengan tingkat signifikansi lebih besar dibandingkan taraf signifikansi yang ditetapkan $(0,484>0,05)$. Maka dari itu hipotesis ketiga yang menyatakan total asset turnover berpengaruh negatif terhadap financial distress ditolak.

5. Variabel biaya agensi manajerial tidak berpengaruh positif terhadap financial distress. Hal ini dibuktikan dengan melihat koefisien $\beta$ bernilai positif sebesar 7,250. Hasil uji signifikansi terhadap kondisi Financial Distress diperoleh nilai sebesar 0,248 dengan tingkat signifikansi lebih besar dibandingkan taraf signifikansi yang ditetapkan $(0,248>0,05)$. Maka dari itu hipotesis ketiga yang menyatakan biaya agensi manajerial berpengaruh positif terhadap financial distress ditolak.

\section{Saran}

Saran yang dapat diberikan dalam penelitian ini di antaranya:

1. Bagi calon investor baiknya mempertimbangkan tingkat leverage dalam mengambil keputusan karena berdasarkan hasil penelitian faktor tersebut berpengaruh terhadap probabilitas munculnya financial distress.

2. Bagi peneliti yang akan datang diharapkan untuk memperluas sampel penelitian tidak hanya terbatas pada perusahaan 
manufaktur yang terdaftar di Bursa Efek Indonesia. Ada baiknya penelitimendatang juga meneliti faktor-faktor selain rasio keuangan yang sudah digunakan sebagai variabel penelitian seperti Quick Ratio, Return On Equity, Debt to Equity Ratio dan sebagainya.

\section{DAFTAR PUSTAKA}

Alifiah, Mohd Norfian, et al., (2012). Prediction of Financial Distress Companiesin The Consumer Product Sector in Malaysia. Journal of Accounting and Finance, Malaysia.

Almilia, Luciana Spica dan Kristijadi. (2003). Analisis Rasio Keuangan Untuk Memprediksi Kondisi Financial Distress Perusahaan Manufaktur yang Terdaftar di Bursa Efek Jakarta. Journal of Accounting. Volume 7, No. 2.

Andre, Orina. (2013). Pengaruh Profitabilitas, Likuiditas, dan Leverage dalam Memprediksi Financial Distress (Studi Empiris pada Perusahaan Aneka Industri yang Terdaftar di BEI). Skripsi. Program Studi Akuntansi, Fakultas Ekonomi, Universitas Negeri Padang.

Ang, Robert. (1997). Buku Pintar Pasar Modal Indonesia. Jakarta: Media Stuff.

Ardiyanto, Feri Dwi. (2011). Prediksi Rasio Keuangan terhadap Kondisi Financial Distress Perusahaan Manufaktur yang Terdaftar di BEI. Skripsi dipublikasikan, Semarang: Fakultas Ekonomi Universitas Diponegoro.

Brahmana, Rayenda K. (2007). Identifying Financial Distress Condition in Indonesia Manufacture Industry. Birmingham Business School,
University of Birmingham United Kingdom. Halaman 1-19.

Brigham, E.F \& Houston, J.F. (2010). Dasar Dasar Manajemen Keuangan Buku 1 (11 Ed). (Terjemahan Ali Akbar Yulianto), Jakarta: Salemba Empat (Edisi Asli Diterbitkan Tahun 2007 Oleh Cengage Learning Asia Pte Ltd).

Darsono, Ashari. (2009). Aplikasi Analisis Laporan Keuangan. Yogyakarta: Liberty.

Deanta. (2009). Memahami Pos-Pos dan AngkaAngka dalam Laporan Keuangan untuk Awan. Yogyakarta: Gava Media.

Fachrudin, K.A. (2008). Kesulitan Keuangan Perusahaan dan Personal. Medan: Usu Press.

Fadhilah, Rahmi. (2014). Pengaruh Good Corporate Governance terhadap Tax Avoidance. Skripsi. Universitas Negeri Padang.

Fraser, Lyn M. Dan Aileen Ormiston. (2008). Memahami Laporan Keuangan. Edisi Ketujuh. Jakarta: Indeks.

Ghozali, Imam. (2011). Ekonometrika: Teori, Konsep, dan Aplikasi dengan SPSS 17. Semarang: Universitas Diponegoro.

Hanifah, Oktita Earning dan Purwanto, Agus. (2013). Pengaruh Struktur Corporate Governance dan Financial Indicators terhadap Kondisi Financial Distress: Studi pada Perusahaan Manufaktur yang Terdaftar di Bursa Efek Indonesia Periode 2009-2011. Journal of Accounting, Vol.2 No.2.

Hapsari, E. I. (2012). Kekuatan Rasio Keuangan Dalam Memprediksi Kondisi Financial Distress Perusahaan Manufaktur di 
BEI. Jurnal Dinamika Manajemen. Vol.4, No.2, Halaman 184-191.

Hendra, S. Raharja Putra. (2009). Manajemen Keuangan dan Akuntansi untuk Eksekutif Perusahaan. Jakarta: Raja Grafindo Persada.

Hidayat, Muhammad Arif. (2013). Prediksi Financial Distress Perusahaan Manufaktur di Indonesia (Studi Empiris pada Perusahaan Manufaktur yang Terdaftar di Bursa Efek Indonesia Periode 2008-2012). Skripsi. Fakultas Ekonomika Dan Bisnis, Universitas Diponegoro.

Jensen, M., C., dan W. Meckling (1976). Theory of the Firm: Managerial Behavior, Agency Cost and Ownership Structure. Journal of Finance Economic 3:305360 ,

Kasmir. (2013). Analisis Laporan Keuangan, Ed.1-6. Jakarta: PT Raja Grafindo Persada.

Nella, R. (2011). Analisis Rasio Keuangan dalam Memprediksi Financial Distress Perusahaan Wholesale and Retail Trade yang Terdaftar di Bursa Efek Indonesia. Journal of Accounting: 1-14.

Platt, H.D., and M.B. Platt. (2002). Predicting Corporate FinancialDistress:Reflections on Choice-Based Sample Bias. Journal of Economic and Finance. (Vol. 26. Summer) No.2

Pramuditya, Andhika Yudha. (2014). Analisis Pengaruh Mekanisme Corporate Governance terhadap Kemungkinan Perusahaan Mengalami Kondisi Financial Distress (Studi Empiris Perusahaan Manufaktur yang Terdaftar di Bursa Efek Indonesia Tahun 20102012). Skripsi. Semarang: Program
Sarjana (S1) Fakultas Ekonomika dan Bisnis Universitas Diponegoro.

Pranowo, K. (2010). Determinant of Corporate Financial Distress in an Emerging Market Economy: Empirical Evidence from the Indonesian Stock Exchange 2004-2008. International Research Journal of Finance and Economics. Issue 52. pp. 80-88.

Rahmy, R. (2015). Pengaruh Profitabilitas, Financial Leverage, Sales Growth, dan Aktivitas terhadap Financial Distress (Studi Empiris pada Perusahaan Manufaktur yang Terdaftar di BEI Tahun 2009-2012). Journal of Accounting, Vol. 3, No. 1.

Saleh, Amir dan Sudiyatno, Bambang. (2013). Pengaruh Rasio Keuangan untuk Memprediksi Probabilitas Kebangkrutan pada Perusahaan Manufaktur yang Terdaftar di Bursa Efek Indonesia. Journal of Management. Vol. 2, No.1.

Sugiyono. (2012). Metode Penelitian Alfabeta Kuantitatif Kualitatif dan $R \& D$. Bandung: Alfabeta.

Triwahyuningtias, Meilinda dan Muharam, Harjum. (2012). Analisis Pengaruh Struktur Kepemilikan, Ukuran Dewan, Komisaris Independen, Likuiditas, dan Leverage terhadap Terjadinya Kondisi Financial Distress: Studi pada Perusahaan Manufaktur yang Terdaftar di Bursa Efek Indonesia Tahun 20082010. Journal of Management. Vol.1, No.1.

Widarjo, Wahyu dan Setiawan Doddy. (2009). Pengaruh Rasio Keuangan terhadap Kondisi Financial Distress Perusahaan Otomotif. Jurnal Bisnis dan Akuntansi. Vol. 11, No. 2, Agustus 2009. 
ARSINDA INGGAR PAWITRI, MUNIYA ALTEZA

Analisis Financial Distress yang Dipengaruhi Likuiditas, Profitabilitas, Leverage, Operating Capacity, dan Biaya Agensi Manajerial 